\title{
TCF3-PBX1 Fusion Protein Expression
}

National Cancer Institute

\section{Source}

National Cancer Institute. TCF3-PBX1 Fusion Protein Expression. NCI Thesaurus. Code C37226.

Expression of a fusion protein that results from a $\mathrm{t}(1 ; 19)(\mathrm{q} 23 ; \mathrm{p} 13)$ translocation, which involves the human genes E2A and PBX1 and is associated with B lymphoblastic leukemias. 